Jurnal Indonesia Sosial Teknologi:p-ISSN: 2723 - 6609

e-ISSN :2745-5254

Vol. 2, No.12 Desember 2021

\title{
KOMPLEKSITAS OPERASI, KONTIJENSI, PERGANTIAN AUDITOR PADA AUDIT REPORT LAG DENGAN PEMODERASI SPESIALISASI AUDITOR
}

\author{
Maria Yulia Dwi Rengganis ${ }^{1}$, Luh Putri Mas Mirayani ${ }^{2}$ \\ Universitas Mahasaraswati Denpasar \\ Email: mariayuliadwi@unmas.ac.id ${ }^{1}$, putrimasmirayani@unmas.ac.id ${ }^{2}$.
}

\begin{abstract}
Abstrak
Penelitian bertujuan untuk menguji pengaruh kompleksitas operasi, kontinjensi, dan pergantian auditor pada audit report lag dengan dimoderasi oleh spesialiasi auditor. Populasi penelitian ini adalah perusahaan otomotif yang terdaftar di Bursa Efek Indonesia (BEI) periode 2017-2020. Sampel sebanyak 44 perusahaan amatan diperoleh menggunakan metode purposive sampling. Data penelitian adalah data sekunder dan diperoleh dengan metode observasi non partisipan. Jenis penelitian yang digunakan dalam penelitian ini adalah penelitian kuantitatif yaitu penelitian sistematis atas fenomena serta kausalitas hubungan, berdasarkan pengujian teori dengan variabel yang dikur dengan angka dan dianalisis dengan prosedur statistik. Teknik analisis yang digunakan adalah analisis regresi berganda dengan menggunakan uji MRA (Moderated Regression Analysis). Hasil penelitian menunjukkan bahwa kompleksitas operasi dan kontinjensi berpengaruh positif dalam menyebabkan audit report lag yang lebih panjang, sedangkan pergantian auditor dan spesialisasi auditor tidak berpengaruh pada audit report lag. Spesialisasi auditor hanya mampu memperlemah pengaruh kompleksitas operasi pada audit report lag, dan tidak mampu memoderasi pengaruh kontijensi dan pergantian auditor pada audit report lag.
\end{abstract}

Kata kunci: audit report lag, kompleksitas operasi, kontinjensi, pergantian auditor, spesialisasi auditor

\section{Abstract}

The study aims to examine the effect ofoperational complexity, contingency, and change of auditors in the audit report lag withmoderated by specializationthe auditor. The population of this research iscompany automotive listed onStock Exchange Indonesia (BEI) in the period 2017-2020. A sample of 44 company observations obtained usingmethod. Purposive samplingData study issecondary data obtained with the method non-participant observation. The type of research used in this research is quantitative research, namely systematic research on phenomena and causality relationships, based on theory testing with variables measured by numbers and analyzed by statistical procedures. The analysis technique used is multipleregression analysis using the MRA (testModerated Regression Analysis). The results of study showed that the complexity of operating and contingencieseffect positivein causing the audit reportlag, that longer whereas change of auditor and auditor specialization has 
no effect on the audit reportlag. Specialization auditor only able to weaken the influence of complexity of the operation on audit report lag, and not able to moderate contingency influence and change of auditors in the audit reportlag

Keywords: audit report lag, operating complexity, contingencies, auditor turnover, auditor specialization

\section{Pendahuluan}

Perusahaan yang terdaftar di BEI adalah perusahaan go public dengan demikian perusahaan-perusahaan tersebut memiliki beberapa kewajiban yang harus dipenuhi salah satunya kewajiban yang paling utama adalah pemenuhan pelaporan keuangan atau annual report yang telah diaudit oleh Akuntan Publik. Menurut (Dewi dkk. 2019) annual report adalah mekanisme yang dilakukan perusahaan untuk menyampaikan informasi mengenai operasional perusahaan dalam bentuk pengukuran ekonomi dan kualitatifnya mengenai kinerja manajemen yang mengelola operasional perusahaan. Annual report haruslah memenuhi empat karakteristik yaitu dapat dipahami, diandalkan, relevan, dan dapat diperbandingkan (IAI, 2012:7).

Annual report digunakan oleh investor dan kreditor sebagai dasar pengambilan keputusan, karena itu ketepatan waktu penyampaian laporan keuangan tersebut sangat penting bagi para pemakainya. Ketepatan waktu penyampaian bagi pemakai berpengaruh kepada nilai dan kualitas laporan itu sendiri, selain itu ketepatan waktu penyampaian laporan akan berdampak pada reaksi pasar baik negatif maupun positif.

Namun menyampaikan laporan keuangan yang tepat waktu juga menemukan berbagai kendala salah satunya adalah keharusan untuk mengaudit laporan publikasi tersebut oleh akuntan publik. Pada umumnya tujuan audit bukan untuk membenarkan atau menyalahkan laporan keuangan namun hanya sebatas memberikan opini atas laporan tersebut apakah telah disajikan sesuai wajar atau tidak sesuai dengan Standar Akuntansi yang berlaku umum. Maka dari itu, penting untuk dilakukan audit atas laporan keuangan yang dibuat oleh manajemen perusahaan karena dibutuhkan pihak ketiga yang netral yang akan memberikan pendapat atas kewajaran laporan keuangan yang bersangkutan.

(Hernita, 2020) memberikan pernyataan bahwa hal yang mempengaruhi ketepatwaktuan perusahaan menyampaikan laporan keuangannya pada publik adalah waktu auditor menyelesaikan pekerjaan auditnya. Dalam proses audit, pekerjaan audit dihitung sejak akhir periode perusahaan bersangkutan sampai waktu publikasi pernyataan opini audit. Perbedaan waktu tutup buku laporan keuangan perusahaan dengan waktu penyelesaian laporan auditor disebut sebagai audit delay atau audit report lag.

Kompleksitas operasi suatu perusahaan tergantung pada keberadaan, jumlah dan lokasi unit perusahaan (anak cabang) serta diversifikasi jalur produk dan pasarnya. Kompleksitas operasi ini terbentuk dari pembagian departemen atau unit perusahaan yang memiliki fokusnya masing-masing dan berdiri secara nyata sesuai lini bisnisnya. Kompleksitas ketergantungan akan semakin terbentuk dikarenakan adanya berbagai 
jenis jumlah pekerjaan unit yang membawa permasalahan manajerialnya sendiri sehingga membuat organisasi menjadi lebih rumit (Hapsari, 2020). (Darmawan \& Widhiyani 2017) memberikan bukti empiris bahwa keberadaan kompleksitas operasi ini akan memberikan pengaruh positif terhadap audit report lag, karena semakin kompleks operasional suatu perusahaan membuat auditor memerlukan waktu yang lebih panjang untuk menyelesaikan laporan auditnya. Namun bukan berarti semua peneliti menemukan hasil yang sama, di sisil lain penelitian milil (gruningrum \& Wirakusuma 2013) serta (Hasibuan \& Abdurahim 2017) tidak ada pengaruh yang signfikan yang diberikan keberadaan aktivitas operasi perusahaan yang kompleks dengan jangka waktu penyelesaian laporan audit.

PSAK Nomor 57 mengatur pengakuan kewajiban kontijensi dan aset kontinjensi. Kontijensi adalah situasi dimana perusahaan mengalami kondisi kerugian maupun keuntungan dan baru dapat dikonfirmasikan setelah terjadinya atau tidak terjadinya satu atau lebih peristiwa yang tidak pasti terjadi di masa depan. Pelaporan kontijensi yang mengandung ketidakpastian ini akan mempengaruhi lamanya waktu yang dibutuhkan auditor untuk melakukan pemeriksaaan laporan keuangan. Ketika auditor memperoleh informasi adanya situasi kontijensi, auditor harus melakukan pemeriksaan yang lebih lama karena harus melakukan evaluasi materialitas dan memberi pengungkapan penejlasan tambahan pada laporan audit (http://ikarosalia.wordpress.com). Demikian halnya saat mengaudit situasi kontijensi diperlukan prosedur audit yang lebih lengkap sehingga waktu yang dibutuhkan auditor untuk menyelesaikan pekerjaan auditnya menjadi lebih panjang tentunya berdampak pada audit report lag. (Dewi \& Suputra 2017) memberikan pernyataan empis bahwa keberdaan situasi kontijensi ini akan mempengaruhi pemenuhan audit report lag. Namun hal ini dibantah oleh penelitian yang dilakukan oleh (Fitriyani dkk. 2015); dan (Putra dkk. 2021) yang menyatakan bahwa meskipun ada situasi kontijensi hal tersebut tidak akan mempengaruhi lamanya waktu yang dibutuhkan auditor untuk menyelesaikan laporan auditnya.

Jika dilihat secara eksternal kompleksitas operasi dan kontijensi yang menyebabkan keterlambatan laporan audit, namun faktor internal dari sisi auditornya sendiri juga mempengaruhi lamanya waktu pengerjaan audit. Salah satunya adalah keharusan perusahaan melakukan pergantian auditor ketika berakhirnya masa perikatan auditee dengan auditor. Peraturan Menteri Keuangan Republik Indonesia Nomor 17/PMK.01/2008 Pasal 3 Ayat 1, menetapkan dimana pemberian jasa audit umum atas laporan keuangan klien hanya dapat dilakukan oleh Kantor Akuntan Publik paling lama untuk 6 (enam) tahun buku berturut-turut dan oleh seorang akuntan paling lama untuk 3 (tiga) tahun buku berturut-turut. Sebelumnya (Telaumbanua et al., 2020) telah melakukan penelitian mengenai hubungan pergantian auditor dan audit report lag, dalam penelitiannya ditemukan bahwa memang benar adanya pergantian auditor perusahaan akan berpengaruh pada semakin panjangnya waktu yang dibutuhkan auditor untuk menyelesaikan pekerjaan auditnya. Namun sebaliknya penelitian yang dilakukan oleh (Indrayani \& Wiratmaja, 2021) memberikan bukti empiris bahwa meskipun 
perusahaan melakukan pergantian pada auditornya hal itu sama sekali tidak memberikan pengaruh pada audit report lag.

Adanya hasil yang masih terus menerus inkonsisten dan saling bertentangan membuat peneliti berkeinginan adanya variabel lain yang dapat memperkuat atau memperlemah pengaruh langsung yang ada. Variabel yang diduga dapat berperilaku sebagai variabel moderasi yang dapat memperlemah dan memperkuat hubungan tersebut adalah spesialisasi auditor. (Raya \& Laksito, 2019) memberikan pernyataan bahwa auditor yang telah dilabeli dengan spesialiasi industri tertentu dianggap lebih mampu menyelesaikan proses audit lebih cepat yang menjadi alasan hal ini adalah auditor tersebut pastinya memeiliki pengetahuan yang lebih baik mengenai industri yang digelutinya dibandingkan auditor yang tidak memiliki spesialisasi industri yang tentu akhirnya berdampak pada audit report lag.

Penelitian sebelumnya milik (Dewi \& Suputra 2017) menggunakan periode waktu tahun 2012 - 2015 dengan menggunakan sampel perusahaan porperty dan real estate. Penelitian ini menggunakan perusahaan otomotif sebagai populasi dan mengambil periode penelitian 2017-2020. Perusahaan otomotif dipilih karena perusahaan yang dianggap sebagai salah satu sektor yang berpengaruh besar terhadap penerimaan Negara, yang secara tidak langsung akan mempengaruhi sektor utamanya yakni sektor manufaktur. Selain itu, banyak investor yang berkeinginan menanamkan modalnya pada perusahaan otomotif karena profit masa depan yang semakin menjanjikan. Investor membutuhkan informasi yang tepat waktu dari laporan keuangan untuk pengambilan keputusan, sehingga adanya audit report lag akan mempengaruhi relevansi informasi yang akan diperoleh. Hal ini yang menjadi dasar peneliti melakukan penelitian kembali atas hal tersebut dikarenakan (1) perusahaan otomotif mengalami peningkatan yang cukup signifikan maka dari itu sampel yang dipilih oleh peneliti adalah perusahaan otomotif; (2) adanya pandemi di tahun 2017 menjadi alasan peneliti mencoba melakukan penelitian ulang atas variabel yang ada dengan mengubah periode waktu terbaru dibandingkan dengan penelitian-penelitian sebelumnya sehingga dapat memberikan gambaran terkini secara lebih akurat mengenai hubungan antar variabel yang diteliti dalam penelitian ini; (3) masih ditemukan research gap atas pengaruh variabel independen dan dependen yang digunakan dalam penelitian ini. Berdasarkan uraian tersebut, maka rumusan masalahnya adalah bagaimana pengaruh kompleksitas operasi, kontinjensi, pergantian auditor, dan bagaimana pengaruh ketiga variabel tersebut terhadap audit report lag ketika dimoderasi oleh spesialisasi auditor?

\section{Metode Penelitian}

Bentuk penelitian yang dilakukan peneliti adalah penelitian asoosiatif dengan pendekatan kuantitaif. Variabel dependent dalam penelitian ini adalah audit report lag. Pengukuran yang digunakan peneliti sebagi pengukuran variabel tersebut dengan menghitung jumlah hari sejak tanggal tutup buku sampai tanggal publikasi laporan audit 
Indikator untuk masing-masing variabel independen yang digunakan dalam penelitian ini adalah sebagai berikut. Variabel $\mathrm{X}_{1}$ yaitu kompleksitas operasi diukur dengan menghitung banyaknya anak perusahaan yang dimiliki perusahaan induk yang dijadikan sampel dalam penelitian. Variabel $\mathrm{X}_{2}$ yaitu kontijensi diukur dengan menggunakan dummy, dimana perusahaan dengan kontijensi diberikan nilai 1 sedangkan perusahaan yang tidak melakukan laporan kontijensi diberi nilai 0. Variabel $\mathrm{X}_{3}$ yaitu pergantian auditor juga diukur menggunakan dummy, dimana perusahaan yang melakukan pergantian dinilai 1 dan yang tidak melakukan pergantian dinilai 0. Dan terakhir variabel moderasi $\left(\mathrm{X}_{4}\right)$ yaitu spesialisasi auditor diukur dengan menjumlahkan perusahaan otomotif yang diaudit oleh KAP yang sama dibagi dengan total perusahaan otomotif yang terdaftar di BEI dan hasil perhitungannyan dikategorikan dengan skala nominal yaitu dummy. Saat nilai dari perhitungan sama dengan atau lebih dari 0.1 artinya auditor tersebut dapat dikategorikan sebagai spesialis industri dinilai 1 sedangkan jika nilai yang diperoleh di bawah 0.1 artinya auditor tersebut tidak termasuk spesialis industri diberi nilai 0 .

Lokasi yang digunakan dalam melakukan penelitian ini adalah BEI dan data diperoleh dari www.idx.co.id berupaka laporan keunagan perusahaan amatan dengan periode waktu 2017 - 2020. Data penelitian dikumpulkan dengan metode observasi nonpartisipan. Populasi yang digunakan dalam penelitian ini adalah seluruh perusahaan sektor otomotif yang terdaftar di BEI periode 2017 - 2020. Teknik nonprobability sampling dengan metode purposive digunakan sebagai metode pemilihan sampel, sehingga total sampel yang digunakan dalam penelitian ini adalah 44 perusahaan amatan. Jenis data yang digunakan adalah jenis data sekunder dengan teknik pengumpulan data menggunakan metode dokumen yaitu menggunakan laporan keuangan yang telah terpublikasikan oleh perusahaan sampel yang dapat diakses melalui www.idx.co.id.

Analisis data yang digunakan dalam penelitian ini terdiri dari statistik deskriptif, uji asumsi klasik, dan analisis regresi berganda. Uji normalitas, uji autokorelasi, dan uji heterokedastisitas adalah bagian dari uji asumsi klasik yang digunakan dalam penelitian ini. Sementara itu, pengujian regresi berganda menggunakan Moderated Regression Analysis (MRA). MRA merupakan teknik analisis data khusus regresi linier berganda dimana dalam persamaan regresinya mengandung unsur interaksi atau moderasi. Adapun rumus yang digunakan adalah sebagai berikut: 


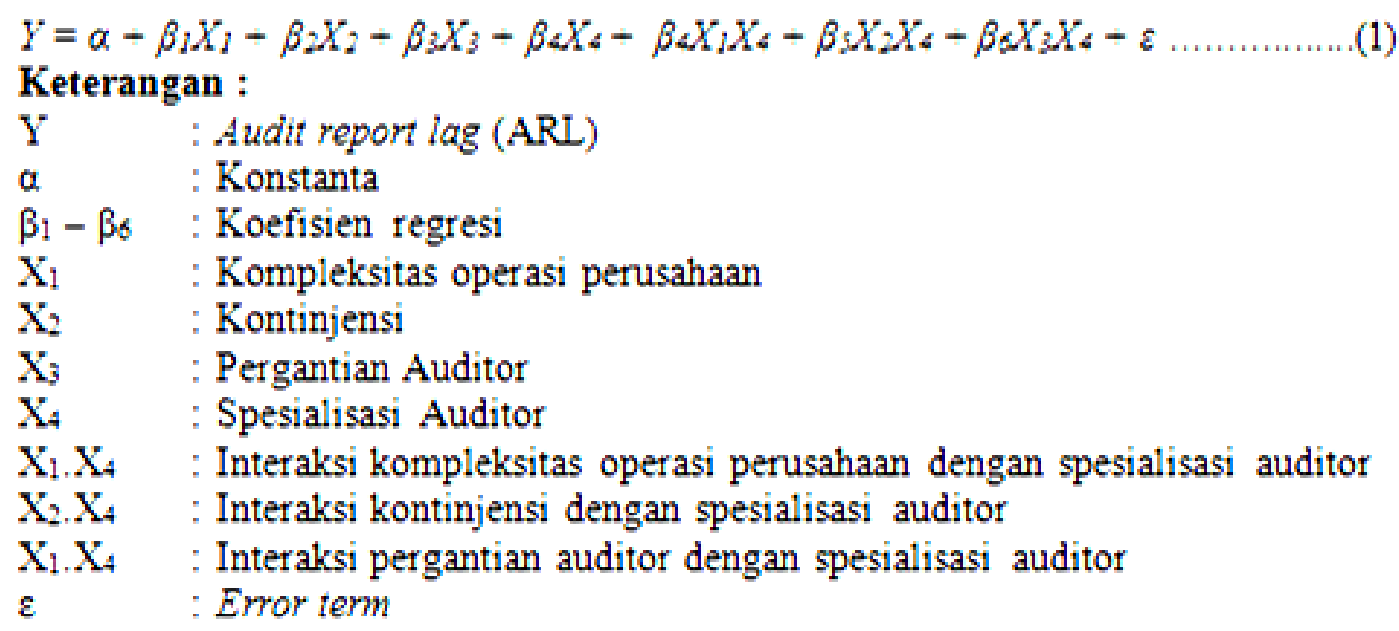

\section{Hasil dan Pembahasan}

Uji asumsi klasik dilakukan sebelum dilakukannya analisis regresi linier berganda. Hasil uji asumsi klasik disajikan seperti Tabel 1.

Tabel 1.
Hasil Uji Asumsi Klasik

\begin{tabular}{lccc}
\hline \multirow{1}{*}{ Variabel } & Normalitas & Autokorelasi & $\begin{array}{c}\text { Heterokedastisit } \\
\text { as }\end{array}$ \\
\cline { 2 - 4 } & $\begin{array}{c}\text { Asymp. Sig. } \\
\text { (2-tailed) }\end{array}$ & $\begin{array}{c}\text { Durbin - } \\
\text { Watson }\end{array}$ & Signifikansi \\
\hline Kompleksitas Operasi $\left(\mathrm{X}_{1}\right)$ & & & 0,654 \\
Kontinjensi $\left(\mathrm{X}_{2}\right)$ & 0,311 & 2,046 & 0,989 \\
Pergantian Auditor $\left(\mathrm{X}_{3}\right)$ & & & 0,841 \\
Spesialisasi Auditor $\left(\mathrm{X}_{4}\right)$ & & & 0,565 \\
\hline
\end{tabular}

Sumber : Data diolah, 2021

Pengujian normalitas dalam penelitian ini menggunakan uji K-S (KolmogorovSmirnov) dan hasilnya ditunjukkan pada Tabel 1. Tabel 1. Menunjukkan nilai asymp. Sig. 2 tailed sebesar 0.311 yang lebih besar dari $\alpha=0.05$ hal ini menunukkan bahwa data yang digunakan dalam penelitian ini berdistribusi normal.

Uji autokorelasi ini adalah pengujian yang dilakukan untuk melihat adanya korelasi antara periode $(\mathrm{t})$ dengan periode sebelumnya $(\mathrm{t}-1)$. Gangguan autokorelasi dapat dilihat dengan menggunakan uji Durbin Watson, dengan kriterianya bila dU $<\mathrm{dW}$ $<$ 4-dU maka tidak terjadi autokorelasi (Ghozali, 2016). Hasil uji dapat dilihat pada Tabel 1. Menunjukkan nilai $1,7200<2,046<2,280$ (4-1,7200), sehingga dapat disimpulkan bahwa dalam model regresi ini tidak terjadi autokorelasi.

Uji Glejser digunakan untuk melakukan uji heteroskedastisitas dan hasil pengujiannya ditunjukkan pada Tabel 1. Nilai signfikansi untuk masing-masing variabel bebas (kompleksitas operasi, kontijensi, pergantian auditor, dan spesialisasi auditor) adalah sebagai berikut $0.654 ; 0.968 ; 0.841$; dan 0.565 . Keempat nilai signfikansi 
variabel bebas tersebut menunjukkan nlai lebih besar dari $\alpha=0.05$ artinya tidak ada persamaan nilai variance pada nilai residual sehingga tidak terjadi heteroskedastisitas pada persamaan model regresi.

Setelah dilakukan uji ausmsi klasik, maka selanjutnya dilakukan uji regresi linier berganda yang didalamnya termasuk analisis koefisien determinasi $\left(\mathrm{R}^{2}\right)$, uji kelayakan model (Uji F), dan uji hipotesis (uji t). Uji MRA adalah uji regresi linier berganda yang digunakan. Adapun, hasil pengujian tersebut ditunjukkan dalam Tabel 2, seperti dibawah ini.

Tabel 2.

Hasil Uji Moderated Regression Analysis

\begin{tabular}{|c|c|c|c|c|c|}
\hline & & B & $t$ & Sig. & $\begin{array}{l}\text { Hasil Uji } \\
\text { Hipotesis }\end{array}$ \\
\hline \multicolumn{2}{|c|}{ (Constant) } & 11.599 & 1.612 & 0.016 & - \\
\hline \multicolumn{2}{|c|}{ Kompleksitas Operasi $\left(\mathrm{X}_{1}\right)$} & 0.698 & 0.481 & 0.033 & $\mathrm{H}_{1}$ diterima \\
\hline \multicolumn{2}{|c|}{ Kontinjensi $\left(\mathrm{X}_{2}\right)$} & 3.905 & 0.897 & 0.036 & $\mathrm{H}_{2}$ diterima \\
\hline \multicolumn{2}{|c|}{ Pergantian Auditor $\left(\mathrm{X}_{3}\right)$} & 4.926 & 1.390 & 0.073 & $\mathrm{H}_{3}$ ditolak \\
\hline \multicolumn{2}{|c|}{ Spesialisasi Auditor $\left(\mathrm{X}_{4}\right)$} & -0.558 & -0.045 & 0.064 & $\mathrm{H}_{4}$ ditolak \\
\hline \multicolumn{2}{|c|}{ Interaksi $\mathrm{X}_{1} . \mathrm{X}_{4}$} & -0.447 & -0.137 & 0.032 & $\mathrm{H}_{5}$ diterima \\
\hline \multicolumn{2}{|c|}{ Interaksi $\mathrm{X}_{2} \cdot \mathrm{X}_{4}$} & 4.775 & 0.738 & 0.465 & $\mathrm{H}_{6}$ ditolak \\
\hline \multicolumn{2}{|c|}{ Interaksi $\mathrm{X}_{3}, \mathrm{X}_{4}$} & -7.166 & -1.456 & 0.154 & $\mathrm{H}$ - ditolak \\
\hline R Square & $=0,282$ & & & & \\
\hline $\mathrm{F}$ & $=0.461$ & & & & \\
\hline Signifikansi & $=0,046$ & & & & \\
\hline
\end{tabular}

Nilai $\mathrm{R}^{2}$ yang ditunjukkan pada Tabel 2. Sebesar 0.282 atau 28.2 persen, dan hal ini berarti peruabahan atas audit report lag sebesar 28.2 persen dijelaskan oleh variabel kompleksitas operasi perusahaan, kontijensi, pergantian auditor, spesialisasi auditor, interaksi antara kompleksitas operasi dengan spesialisasi auditor, interaksi kontijensi dengan spesialisasi auditor, dan interaksi pergantian auditor dengan spesialisasi auditor. Sisanya sebesar 71.8 persen dijelaskan oleh faktor-faktor lain di luar model regresi ini.

Pada Tabel 2. Nilai signfikansi ditunjukkan sebesar 0.046 lebih kecil dari $\alpha=0.05$ hal ini artinya bahwa model penelitian yang digunakan dalam penelitian ini dinyatakan layak. Model persamaan ini artinya dapat digunakan untuk menguji pengaruh variabel independent dan variabel moderasi terhadap variabel dependent. Melihat nilai MRA yang ditunjukkan pada Tabel 2, maka persamaan regresi yang dihasilkan adalah sebagai berikut.

$Y=11.599+0.698 X 1+3.905 X 2+4.926 \mathrm{X} 3-0.558 \mathrm{X} 4-0.447 \mathrm{X} 1 * \mathrm{X} 4-4.775 \mathrm{X} 2 * \mathrm{X} 4-$ $7.166 \times 3 * X 4$

Nilai konstanta yang ditunjukkan pada persamaan di atas 11.599 arti nilai ini saat variabel kompleksitas operasi, kontijensi, dan pergantian auditor bernilai konstan maka terjadi peningkatan pada audit report lag selama 11.599 atau 12 hari. Koefisien regresi $\mathrm{X}_{1}$ (kompleksitas operasi) sebesar positif 0.698 artinya apabila terjadi 
peningkatkan pada kompleksitas operasi maka akan menyebabkan peningkatan pada lamanya audit report lag sebesar 0.698 hari dengan asumsi variabel lainnya berperilaku konstan. Koefisien regresi untuk $\mathrm{X}_{2}$ (kontijensi) adalah sebesar 3.905 variabel ini menggunakan penilaian dummy dimana perusahaan yang melaporkan kontijensi diberikan nilai 1 dan yang tidak melaporkan kontijensi diberikan nilai 0 , nilai koefisien regresi tersebut berarti apabila terjadi peningkatan pada kontijensi perusahaan maka waktu audit akan bertambah selama 3.905 atau 4 hari dengan asumsi variabel lainnya tidak berubah. Koefisien regresi $\mathrm{X}_{3}$ (pergantian auditor) sebesar 4.926 dimana variabel ini juga diukur menggunakan dummy variable, dimana bagi perusahaan yang melakukan pergantian atas Akuntan Publiknya diberikan nilai 1 dan yang tidak melakukan pergantian diberikan nilai 0. Nilai koefisien regresi bertanda positif memberikan arti bahwa apabila terjadi pergantian auditor maka akan terjadi penambahan masa audit report lag sebesar 4.926 atau bertambah sebanyak 5 hari dengan asumsi variabel lainnya tidak berubah. Terakhir koefisien regresi untuk variabel $\mathrm{X}_{4}$ (spesialiasi auditor) menunjukkan nilai negatif sebebesar 0.558 . Hal ini berarti bagi perusahaan yang menggunakan auditor dengan spesialisasi tertentu maka dapat menurunkan lamanya audit report lag sebesar 0.558 dengan asumsi variabel lainnya konstan.

Koefisien regresi interaksi hubungan kompleksitas operasi dan spesialisasi auditor adalah sebesar negatif 0.447 artinya efek moderasi yang diberikan adalah memperlemah. Dapat dijelaskan sebagai berikut apabila interkasi hubungan kompleksitas operasi dan spesialisasi auditor negatif maka ana menurunkan pengaruh langsung yang ditimbulkan kompleksitas operasi pada audit report lag yaitu sebesar 0.447 dengan asumsi variabel lainnya konstan. Demikian halnya dengan koefisien regresi interaksi antara kontijensi dan spesialisasi auditor yang menunjukkan nilai negatif 4.775 artinya dengan adanya spesialisasi auditor maka akan memperlemah hubungan langsung kontijensi terhadap audit report lag sebesar 4.775 dengan asumsi variabel lainnya tidak berubah. Terakhir nilai koefisien regresi interkasi antara pergantian auditor dan spesialisasi auditor menunjukkan nilai negatif 7.166, hal ini juga berarti bahwa adanya spesialisasi auditor sebagai variabel moderasi pada hubungan langsung pergantian auditor dan audit report lag adalah memperlemah. Spesialisasi auditor memperlemah hubungan langsungnya sebesar 7.166 dengan asumsi variabel lainnya konstan atau tidak berubah.

Dalam penelitian ini $\mathrm{H}_{1}$ diterima hal ini dibuktikan dengan nilai unstadardized residual sebesar 0.698 dan signifikansi 0.033 lebih kecil dari $\alpha=0.05$ artinya kompleksitas operasi berpengaruh secara positif dan signifikan terhadap audit report lag. Menurut teori kepatuhan auditor dan perusahaan akan berusaha sebisa mungkin untuk menyelesaikan laporan audit atas annual report dengan tepat waktu agar tidak melanggar aturan yang berlaku namun hal tersebut tetap mengalami kendala karena laporan perusahaan auditeenya kompleks sesuai dengan kompleksitas operasi perusahaan yang bersangkutan. (Darmawan \& Widhiyani 2017); (Fitriyani, dkk. 2015) serta (Dewi \& Suputra, 2017) menemukan hasil yang serupa dengan penelitian ini 
dimana dalam penelitian mereka menyebutkan bahwa semakin kompleks operasional suatu perusahaan maka waktu yang dibutuhkan auditor untuk menyelesaikan laporan auditnya akan semakin lama. Perusahaan dengan kompleksitas yang tinggi artinya memiliki anak perusahaan yang tidak sedikit dan banyaknya anak perusahaan itu sejalan dengan laporan konsolidasi yang mengikutinya sehingga lingkup kerja auditor menjadi semakin luas dan banyak yang menyebabkan auditor membutuhkan waktu lebih lama untuk menyelesaikan langkah-langkah prosedur audit sesuai aturan yang berlaku dan berdampak pada audit report lag.

Selanjutnya $\mathrm{H}_{2}$ dalam penelitian ini juga diterima dibuktikan dengan nilai unstandardized residual sebesar 4.255 dengan nilai signfikansi 0.022 lebih kecil dari $\alpha=0.05$. Hal ini berarti bahwa adanya laporan kontinjensi yang dilaporkan auditee akan menambah waktu kerja audit atau menyebabkan audit report lag semakin panjang. Penelitian ini sejalan dengan penelitian yang dilakukan oleh Saleh (2004) serta Tedja (2011) dimana disebutkan bahwa adanya laporan kontijensi artinya auditor harus mengambil ruang lingkup materialitas yang lebih banyak yang akan berpengaruh pada audit report lag. Dilihat dari signalling theory perusahaan dengan audit report lag yang panjang memberi sinyal negatif pada pembaca laporan keuangan atau sifatnya adalah bad news, ditambah alasan adanya kurang tepat waktu penyelesaian laporan audit karena adanya laporan kontijensi semakin menunjukkan hal yang kurang baik. Salah satunya yang termasuk dalam laporan kontijensi adalah perkara hukum yang mungkin dialami perusahaan sehingga dalam penugasannya auditor wajib mengevaluasi perlakuan akuntansi atas pengungkapan kontijensi tersebut. Kontijensi dalam laporan keuangan perusahaan bersifat kualitatif dan tidak dapat dinyatakan dalam satuan moneter sehingga makin menyulitkan bagi auditor untuk mengevaluasinya berdasarkan aspek materialitas yang telah ditentukan di awal pengerjaan audit. Menurut Saleh (2004) hal inilah yang memperlambat auditor dalam menyelesaikan proses auditnya sehingga pelaporan kontinjensi dapat menyebabkan proses penyelesaian audit dan audit report lag yang lebih lama.

$\mathrm{H}_{3}$ dalam penelitian ini ditolak karena dilihat dari nilai unstandardized resiudal sebesar 0.408 dengan signfikansi 0.879 lebih besar dari $\alpha=0.05$ artinya bahwa pergantian auditor dalam penelitian ini tidak mampu memberikan pengaruh terhadap audit report lag. Hasil penelitian ini sejalan dengan penelitian yang dilakukan oleh Widhiasari dan Budiartha (2016), Sitanggang dan Ariyanto (2015), Megayanti dan Budiartha (2016) yang menyatakan bahwa meskipun perusahaan melalukan pergantian auditornya tidak akan ada pengaruhnya pada audit report lag. Perikatan kerja auditor dengan auditee biasanya dibuat atau dilakukan oleh auditor dalam kurun waktu enam hingga sembilan bulan sebelum masa audit (sebelum tahun fiskal klien berakhir). Artinya auditor memiliki waktu yang cukup lama untuk melakukan persiapan audit, untuk mempelajari operasional perusahaan yang akan diauditnya sehingga auditor sudah bisa melakukan perencanaan yang lebih matang sebelum melakukan pemeriksaan lapangan (Megayanti dan Budiartha, 2016). Menurut Julianto dan Suputra (2016) auditor yang melakukan perencanaan audit yang baik akan dapat menyelesaikan 
pekerjaan auditnya dengan lebih tepat waktu sehingga sesungguhnya pergantian auditor tidak akan mempengaruhi waktu penyelesaian laporan audit atau audit report lag. Selain itu, jika dilihat dari sudut pandang auditor itu sendiri secara mandatory auditor yang bersangkutan akan menjaga nama atau Kantor Akuntan Publik (KAP) tempatnya bernaung karena proses pengerjaan audit yang terlalu lama akan memberikan citra negatif pada KAP bersangkutan. Meskipun auditor yang bersangkutan adalah auditor baru, maka auditor tersebut tetap memiliki kesadaran diri untuk menyelesaikan pekerjaan auditnya tepat waktu karena nantinya dapat mempengaurhi reputasi KAP tempat auditor bersangkutan terikat kerja dan mempengaruhi tingkat kepercayaan klien atas laporan audit yang dikeluarkan.

$\mathrm{H}_{4}$ menyatakan bahwa spesialisasi auditor tidak berpengaruh signifikan terhadap audit report lag dan hal ini dibuktikan melihat nilai unstandardized residual sebesar 0.558 dengan nilai signfikansi 0.064 lebih besar $\alpha=0.05$. Dapat dijelaskan sebagai berikut auditor dengan spesialisasi tertentu atas industri kliennya tidak mempengaruhi jangka waktu penyelesaian laporan audit dan hal ini didukung oleh penelitian yang dilakukan Kusuma, Astuti, \& Harjito (2020). Auditor melakukan spesialisasi bertujuan untuk memperoleh kepercayaan klien dengan lebih baik sehingga auditor bekerja dengan lebih ekonomis. Habib \& Bhuiyan (2011) dan Rahadianto (2012) menyatakan secara teori perusahaan yang diperiksa oleh auditor dengan spesialisasi tertentu akan memperoleh hasil laporan audit lebih cepat karena auditor yang terspesialisasi lebih paham mengenai operasional industri-industri tertentu.

$\mathrm{H}_{5}$ dalam penelitian ini menyatakan bahwa spesialiasi auditor memoderasi pengaruh kompleksitas operasi perusahaan pada audit report lag. Melihat hasil MRA menunjukkan jasil bahwa variabel interaksi spesialisasi auditor dengan kompleksitas operasi memiliki koefisien regresi sebesar -0.447 dengan nilai signifikansi 0,032 lebih kecil dari 0,05. Hal ini berarti bahwa spesialisasi auditor memperlemah pengaruh positif yang diberikan kompleksitas operasi perusahaan pada audit report lag dan $\mathrm{H}_{5}$ diterima. Auditor dengan spesialisasi tertentu mampu menghadapi kompleksitas operasi perusahaan yang lebih tinggi karena auditor tersebut dianggap memiliki jumlah perikatan sejenis lebih banyak, memiliki ragam kerjaan audit yang lebih kompleks, banyak dan berbagai macam klien dengan karakteristik yang berbeda. Adanya kelebihan-kelebihan tersebut menyebabkan auditor yang terspesialisasi memberikan dampak yang signifikan atas audit report lag. Perusahaan dengan kompleksitas operasi yang tinggi memiliki banyak anak perusahaan namun saat dihadapkan dengan auditor terspesialiasi hal itu dapat diselesaikan dengan baik dan pengerjaan audit tetap dapat diselesaikan dengan tepat waktu. Hal ini menjelaskan bahwa pengaruh kompleksitas operasi perusahaan yang positif pada audit report lag dapat diperlemah dengan adanya spesialisasi auditor yang menurunkan jangka waktu penyelesaian kerja audit.

$\mathrm{H}_{6}$ mengenai spesialisasi auditor memoderasi pengaruh kontijensi pada audit report lag ditolak. Hal ini dibuktikan dengan hasil MRA yang menunjukkan bahwa nilai unstandardized residual sebesar -4.775 dengan nilai signifkansi 0,465 lebih besar dari 0,05 artinya bahwa keberadaan spesialisasi auditor tidak mampu memperlemah 
pengaruh positif yang ditimbulkan pelaporan kontijensi perusahaan terhadap audit report lag. Kontijensi merupakan informasi tambahan dari laporan keuangan perusahaan yang sifatnya kualitatif sehingga sulit bagi auditor untuk mengidentifikasi dan mengevaluasi tingkat materialitas dan tingkat relevansinya. Meskipun auditor terspesialisasi memiliki pengalaman dan kemampua yang lebih baik dalam suatu industri tertentu hal tersebut belum bisa menjadi batu loncatan bagi auditor untuk lebih cepat menanggapi informasi kontijensi yang diterima. Menurut Raya \& Laksito (2019) spesialiasasi auditor akan membantu auditor menyelesaikan pekerjaan audit dengan lebih tepat waktu dibandingkan auditor non-spesialis dan juga spesialisai auditor menuntut auditor menghadapi perusahaan dengan industri sejenis sehingga secara teori auditor tersebut dikatakan lebih capable menemukan salah saji material yang mungkin terkandung dalam laporan keuangan yang disajikan oleh klien. Namun di dalam penelitian ini pengetahuan auditor yang terspesialisasi tersebut ditemukan belum dapat menurunkan lamanya jangka waktu audit saat melakukan prosedur-prosedur audit khususnya bagi perusahaan yang melaporkan laporan keuangannya dengan adanya unsur kontijensi sehingga spesialisasi auditor tidak mampu mengurangi audit report lag.

Hipotesis terakhir yaitu $\mathrm{H}_{7}$ menyatakan bahwa spesialisasi audtior memoderasi pengaruh pergantian auditor pada audit report lag ditolak. Hal ini dibuktikan dengan hasil pengujian MRA yang menunjukkan nilai unstandardized coefficient sebesar 7.166 dan nilai signifikansi sebesar 0,154 yang lebih besar dari $\alpha=0,05$. Spesialisasi auditor tidak mampu memperlemah pengaruh langsung pergantian auditor terhadap audit report lag. Hal ini dikarenakan karena pergantian auditor berarti auditor baru yang akan memeriksa perusahaan klien dan auditor tersebut tetap membutuhkan waktu untuk mempelajari industri kliennya meskipun auditor tersebut memiliki spesialisasi industri tertentu. Sebagai auditor dengan perikatan baru auditor harus mempelajari karakteristik perusahaan dan melakukan perbandingan atas laporan keuangan untuk tahun sebelumnya, kedua hal tersebut tentunya memakan waktu dan akan mempengaruhi audit report lag. Bagi auditor baru prosedur audit yang harus dilakukan lepbih banyak dibandingkan dengan auditor yang melanjutkan penugasan dan hal ini akan mempengaruhi lamanya waktu pengerjaan audit. Jika dilihat secara teori, auditor yang terspesialisiasi memiliki pengalaman dan kemampuan yang lebih baik dibandingkan auditor non-spesialisasi. Namun kenyataan di lapangan berbeda auditor yang terspesialisasi belum tentu memiliki pengalaman mengenai industri tertentu lebih banyak dan kemampuan yang lebih tinggi dalam melakukan fungsi audit atas suatu perusahaan. Ada faktor lain yang mempengaruhi banyaknya jumlah klien yang ditangani auditor terspesialisasi antara lain audit fee, profesionalisme, dan relasi. Oleh karena itu, pengukuran spesialisasi auditor menggunakan proporsi jumlah klien dinilai memiliki keterbatasan dimana tidak mampu mencerminkan kompetensi auditor yang sebenarnya. Faktor lain yang dapat menyebabkan auditor pengganti yang berpredikat spesialis tidak mampu memperpendek audit report lag diantaranya tenure audit yang pendek dan tingginya beban kerja. 


\section{Kesimpulan}

Berdasarkan penelitian yang telah dilakukan dapat disimpulkan bahwa kompleksitas operasi dan kontijensi berpengaruh positif pada audit report lag. Di sisi lain pergantian auditor dan spesialisasi auditor tidak berpengaruh pada audit report lag. Dilihar dari hubungan interaksi spesialisasi auditor hanya mampu memperlemah hubungan kompleksitas operasi perusahaan terhadap audit report lag, dan tidak mampu memoderasi pengaruh kontijensi serta pergantian auditor pada audit report lag.

Bagi peneliti selanjutnya dapat merubah proksi pengukuran audit report lag dengan menghitungn hari penyelesaian audit berdasarkan tanggal pada SPK (Surat Perikatan Kerja). Apabila auditor tidak menyelesaikan pekerjaan audit sesuai SPK hal itu dapat dikategorikan keterlambatan proses audit. 


\section{Bibliografi}

Agruningrum, Silvia, \& Wirakusuma, Made Gede. (2013). Pengaruh Profitabilitas, Leverage, Kompleksitas Operasi, Reputasi Kap Dan Komite Audit Pada Audit Delay. E-Jurnal Akuntansi, 5(2), 251-270.

Darmawan, I. Putu Yoga, \& Widhiyani, Ni Luh Sari. (2017). Pengaruh Ukuran Perusahaan, Kompleksitas Operasi Perusahaan Dan Komite Audit Pada Audit Delay. E-Jurnal Akuntansi, 2017(1), 254-282.

Dewi, Gusti Ayu Nyoman Purnama, \& Suputra, I. Dewa Gede Dharma. (2017). Pengaruh Kompleksitas Operasi, Kontinjensi, Pergantian Auditor pada Audit Report Lag dengan Spesialisasi Auditor sebagai Pemoderasi. E-Jurnal Akuntansi, 21(2), 912-941. https://doi.org/10.24843/EJA.2017.v21.i02.p02.

Dewi, I. Gusti Ayu Ratih Permata, Putri, Putu Yudha Asteria, \& Idawati, Putu Diah Putri. (2019). Pengaruh Ketidaktepatwaktuan Pelaporan Keuangan Berpengaruh Pada Reaksi Pasar Perusahaan Manufaktur Yang Terdaftar di Bursa Efek Indonesia Tahun 2016-2017. Jurnal Kumpulan Riset Akuntansi, 10(2), 177-187. https://doi.org/10.22225/kr.10.2.\%25y.177-187.

Fitriyani, Chintya Ayu, Purnamasari, Pupung, \& Maemunah, Mey. (2015). Pengaruh Tenure Audit, Ukuran Kap Dan Kompleksitas Operasi Perusahaan Terhadap Audit Report Lag (Studi Kasus Pada Perusahaan Consumer Goods Yang Terdaftar Di Bursa Efek Indonesia Periode 2010-2014). Prosiding Akuntans, 1(2), 314-322. Retrieved from http://karyailmiah.unisba.ac.id/index.php/akuntansi/article/view/1789/pdf.

Ghozali, Prof. Dr. H. ima. (2016). Aplikasi Analisis Multivariete dengan program IBM SPSS 23. In IBM SPSS 23 (p. 52).

Hapsari, RR. Prima Dita. (2020). Analisis Pengaruh Ukuran Perusahaan, Kompleksitas Operasi Perusahaan, Dan Ukuran Kantor Akuntan Publik (Kap) Terhadap Audit

Report Lag. Journal Civics \& Social Studies, 4(2), 70-81. https://doi.org/10.31980/civicos.v4i2.928.

Hasibuan, Ella Nori Safira, \& Abdurahim, Ahim. (2017). Pengaruh Kompleksitas Operasi, Ukuran Perusahaan, dan Risiko Bisnis terhadap Audit Report Lag: Studi Empiris pada Perusahaan Perkebunan yang Terdaftar di Bursa Efek Indonesia dan Bursa Malaysia Periode 2014-2016. Reviu Akuntansi Dan Bisnis Indonesia, 1(1), 15-24. https://doi.org/10.18196/rab.010102.

Hernita, Tiwi. (2020). Faktor-Faktor yang Mempengaruhi Ketepatan Waktu Penyampaian Laporan Auditan Kepada Stakeholder. Jurnal Manajemen Bisnis, 23(3), 295-308. https://ibn.e-journal.id/index.php/ESENSI/article/view/212.

Indrayani, Putu, \& Wiratmaja, I. Dewa Nyoman. (2021). Pergantian Auditor, Opini Audit, Financial Distress dan Audit Delay. E-Jurnal Akuntansi, 31(4), 880-893. 
https://doi.org/10.24843/eja.2021.v31.i04.p07.

Putra, I. Nyoman Agus Widiana, Rustiarini, Ni Wayan, \& Dewi, Ni Putu Shinta. (2021). Analisis faktor-faktor yang mempengaruhi audit report lag pada perusahaan manufaktur yang terdaftar di bursa efek indonesia tahun 2017-2019. KARMA (Karya Riset Mahasiswa Akuntansi), 1(1), 232-238.

Raya, Victoria Jeniffer, \& Laksito, Herry. (2019). Pengaruh Reputasi Auditor Dan Spesialisasi Industri Auditor Terhadap Audit Report Lag (Studi Empiris Pada Perusahaan Manufaktur Yang Terdaftar Di Bei Tahun 2016 Dan 2017). Diponegoro Journal of Accounting, 8(2), 1-10.

Telaumbanua, Desta Jess Wijawa, Dwisyafitri, Jenny Indah, Sherlia, Bella, Hutabalian, Hermanto, Rahmad, \& Ginting, Wenny Anggeresia. (2020). Pengaruh Pergantian Auditor, Ukuran KAP Dan Laba Rugi Terhadap Audit Report Lag (Studi Empiris Perusahaan Manufaktur Tercatat dalam Daftar di BEI Tahun 2016-2018). Jurnal Ilmiah MEA (Manajemen, Ekonomi Dan Akuntansi), 4(3), 794-810. https://doi.org/10.31955/mea.vol4.iss3.pp794-810. 